\title{
Quantitative reconstruction of Late Cenozoic landscapes: a case study in the Sierra de Atapuerca (Burgos, Spain)
}

\author{
Alfonso Benito-Calvo, ${ }^{\prime *}$ Alfredo Pérez-González ${ }^{2}$ and Josep María Parés ${ }^{3}$ \\ Dipartimento di Scienze della Terra, Università degli Studi di Modena e Reggio Emilia, Largo S. Eufemia, 19. 4 I 100 Modena, Italy \\ 2 Departamento de Geodinámica, Facultad de Ciencias Geológicas, Universidad Complutense, Ciudad Universitaria s/n, Madrid, Spain \\ 3 Department of Geological Sciences, University of Michigan, Ann Arbor, MI, USA
}

\begin{abstract}
*Correspondence to: Alfonso Benito-Calvo, Dipartimento di Scienze della Terra, Università degli Studi di Modena e Reggio Emilia, Largo S. Eufemia, 19. 4I 100 Modena, Italy. E-mail: alfonso@unimore.it
\end{abstract}

Received 5 July 2006;

Revised II April 2007;

Accepted 16 April 2007

\begin{abstract}
We have developed a method to reconstruct palaeorelief by means of detailed geomorphological and geological studies, geostatistical tools, GIS and a DEM. This method has been applied to the Sierra de Atapuerca (NE Duero Basin, Burgos, Spain), allowing us to model a three-dimensional reconstruction of the relief evolution from the Middle Miocene to the present. The modelling procedure is based on geostatistical recovery of the palaeosurfaces characteristic of each geomorphological evolution stage, using polynomial regressions, trend surfaces and kriging. The modelling of morphology trends has been useful in establishing new geological and geomorphological relationships in the geodynamic evolution of this basin, such as uplift quantification, correlation of erosion surfaces and sedimentary units, and the evolution of fluvial base levels. The palaeosurface reconstruction together with an analysis of the slope retreat have allowed us to reconstruct the palaeoreliefs that define the Late Cenozoic landscape evolution of this area, where the Lower and Middle Pleistocene archaeopalaeontological sites of the Sierra de Atapuerca are located. Copyright (C) 2007 John Wiley \& Sons, Ltd.
\end{abstract}

Keywords: palaeorelief; landscape evolution; Cenozoic; Duero Basin; Iberian Peninsula

\section{Introduction}

The geomorphological evolution of a landscape may be the consequence of several stages recorded in the morphologies that constitute the current relief. Temporal differentiation of these forms and their topography represents valuable information, which through the application of the mapping and geostatistical methods of geographical information systems (GISs) can be used to model palaeoreliefs. Palaeotopographic reconstruction is a new area of research that is currently being used to model past geomorphological, geological, hydrological and climatic processes for specific geological times and events (Abbot et al., 1997; Small and Anderson, 1998; Bonnet et al., 2001; Leverington et al., 2002).

In this study, we have developed a method that considers palaeorelief modelling from an integrated perspective, the terrain being reconstructed as a whole for 12 periods extending from the Middle Miocene to the present time. This makes it possible to model the three-dimensional landscape evolution for a temporal range that spans for about $13 \mathrm{Ma}$, including diverse geological conditions through the geodynamic evolution of a basin (endorrheic continental infill, uplift stage, exorrheic regime and fluvial incision).

These models constitute a new database useful for geomorphological and geoarchaeological analysis, which in the study area of the NE Duero Basin (Spain) characterize the evolution of the physical environment of the Sierra de Atapuerca sites. The latter currently form one of the most significant archaeopalaeontological records of the Lower and Middle Pleistocene (Arsuaga et al., 1997; Bermúdez de Castro et al., 1997; Carbonell et al., 2005). These models have been useful for proposing new correlations in the geomorphological evolution of this region, and have allowed a first analysis of the Quaternary and Neogene evolution of terrain morphometric variables. In the same way, the palaeorelief reconstructions provide an useful database that will allow us to establish the geometric and genetic relationships between the external base levels and the freatic endokarstic system where these sites are located (Ortega et al., 2005). 


\section{Regional Setting}

The study region is located in the north-east area of the Cenozoic Duero Basin (north-central Iberian Peninsula, Figure 1(A)), which is delimited to the north and south-east by the Alpine orogens of the Cantabrian and Iberian Ranges (Figure 1(A) and (B)). The Iberian Range constitutes a NW-SE intraplate fold belt (Simón et al., 2002),

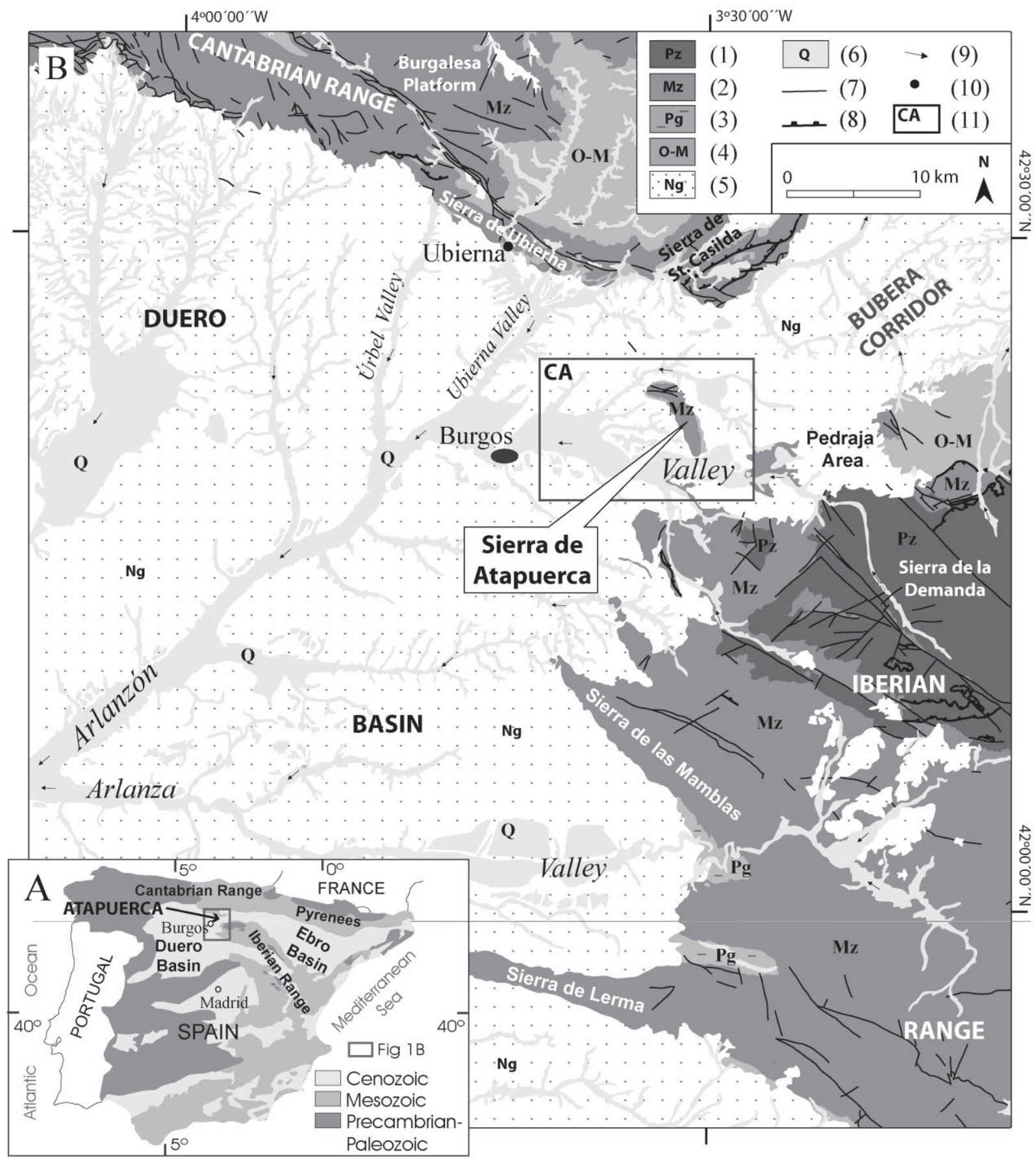

Figure I. Sierra de Atapuerca study area, located in NE Duero Basin between the lberian and Cantabrian Ranges (north-central Spain). (I) Paleozoic; (2) Mesozoic; (3) Paleogene; (4) Oligocene-Lower Miocene; (5) Neogene; (6) Quaternary; (7) faults; (8) thrusts; (9) drainage; (10) towns; (II) central study area, I:10 000 geomorphological map (Figure 2(A)) and area of palaeorelief reconstruction. 
formed in its north-eastern part by a faulted Palaeozoic massif (Sierra de la Demanda, Figure 1(B)) and Mesozoic sediments structured in NW-SE/WNW-ESE anticlines and synclines. The Cantabrian Range was generated by compressive tectonic activity produced by displacement of the Cantabrian Sea crust under the Iberian plate during the Pyrenean deformation (Vergés et al., 2002). In the study area, Cantabrian structure includes E-W and SW-NE low-angle thrusts and thrust-related folds in the mountain fronts (Alonso et al., 1996; Hernaiz et al., 1994). The first compressive movements took place in the Cretaceous-Paleogene, initiating the formation of the Duero Basin and giving rise to transitional and then to endorreich continental deposits. The deformation peak occurred during the Oligocene-Lower Miocene (Castilian Phase), coinciding with the sedimentation of the syn-orogenic complex (Santisteban et al., 1996). During the Lower Miocene the sedimentation of alluvial and lacustrine deposits in Duero Basin took place, represented by several units separated by discontinuities (Figure 2(A) and (B); Calvo et al., 1993; Armenteros et al., 2002). This sequence connected the Duero and Ebro Basins during the Miocene through the Bureba Corridor. Based on correlations between the sedimentary units in the two basins, an initial drainage from SW (Duero Basin) to NE (Ebro Basin) during the Miocene was proposed (Pineda, 1996); however, the most recent correlations between Miocene units do not support this model (Benito and Pérez-González, 2005a). After this endorrheic infill (Upper Miocene-Pliocene), the Duero Basin was opened to the Atlantic Ocean, giving rise to the formation and incision of the Quaternary fluvial network, represented in the study area by the Arlanzón River and tributaries. During the Quaternary, the Arlanzón drainage network was captured by the Ebro tributaries in the Bureba region (Mikes et al., 2004; Benito, 2004). The tectonic activity during the Late Cenozoic is related to compressive (Early and Middle Miocene) and extensional stresses (Late Miocene and Pliocene-Pleistocene), mainly in relationship with the reactivation of previous structures (Hernaiz et al., 1994; Simón et al., 2002; Simón, 2004).

In this context are located the Sierra de Atapuerca (Figures 1(B) and 2(A)). The latter forms a gentle high of Turonian-Lower Santonian limestones and dolostones, surrounded by Cenozoic materials. The Upper Cretaceous sediments were folded during the peak deformation, forming an overturned anticline of NNW-SSE direction, faulted at its northern part.

\section{Geomorphological Evolution}

Palaeolandscape reconstructions start from an initial detailed analysis of the geomorphological evolution of this region. This analysis has been assisted by geomorphological mapping at a scale of 1:10 000 in the Sierra de Atapuerca and the Arlanzón Middle Valley (Figures 1(B) and 2(A)), and at a scale of 1:25 000 in the surrounding area (Figure 1(B)). The latter area includes the other main valleys of this region (of the Arlanza, Lower and Upper Arlanzón, Ubierna and Urbel Rivers) and the link zones between the NE Duero Basin and the Iberian and Cantabrian Alpine Ranges (Burgalesa Platform, Sierra de Ubierna, Sierra de Santa Casilda, Pedraja Area, Sierra de la Demanda, Sierra de las Mamblas and Sierra de Lerma).

The geomorphological evolution of this region is characterized by the development of erosion surfaces related to erosion-sedimentation/uplift cycles during the Neogene (Benito-Calvo and Pérez-González, 2006), and the predominance of fluvial incision of the current valleys in the Pleistocene and Holocene (Figure 2(B), Benito, 2004).

The oldest erosion surface, SE1 (at 1084-1060 m a.s.l. in the Sierra de Atapuerca, Figure 2(A) and (B)), developed during the Oligocene-Lower Miocene, corresponding to the syn-orogenic sedimentation (Zazo et al., 1983; BenitoCalvo and Pérez-González, 2007). The second level (SE2, 1065-1050 m a.s.l.) has been related in adjacent Basque-Cantabrian and Iberian Ranges to alluvial systems (Benito-Calvo and Pérez-González, 2006) composed of conglomerates, sands and shales topped by a limestone layer (Astaracian, Middle Miocene). These sediments are tilted by $2-7^{\circ}$ in contact with the Sierra de Atapuerca (Figures 2(A) and 3), and buried by Upper Miocene horizontal deposits (Figure 2(A)), indicating tectonic uplift of Middle Miocene age. A third erosion surface (SE3, 1030-1035 m a.s.l.) occupies a similar position to the Upper Miocene deposits (Gutiérrez-Elorza and Gracia, 1997; Benito-Calvo and Pérez-González, 2006). In nearby mountains, a fourth level can be distinguished at 950-1000 m a.s.l. (SE4), related to Plio-Pleistocene alluvial fan gravels (Figure 2(B)).

Two erosional surfaces have developed on Miocene flat-lying limestones (Figure 2(B); Benito and Pérez-González, 2005a). The Upper Páramo surface (1010-1031 m a.s.l.) formed in the Upper Turolian-Ruscinian due to erosion and sedimentary processes (fluvial, karstic, aeolian), which affected the lithostratigraphic unit of Upper Páramo Limestones (Figure 2B). During Pliocene, denudation processes in the exorrheic regime eroded the Vallesian-Turolian sediments, exhuming the Lower Páramo Limestones, on which a younger erosional surface developed during the Pliocene-Pleistocene boundary, the Lower Páramo surface (980-1026 m a.s.l., Figure 2(A) and (B)).

During the Quaternary, these Neogene morphologies were incised by the fluvial network, leaving behind a sequence of terraces (Benito, 2004), which in the Arlanzón Valley are comprised of 14 levels and the present floodplain 


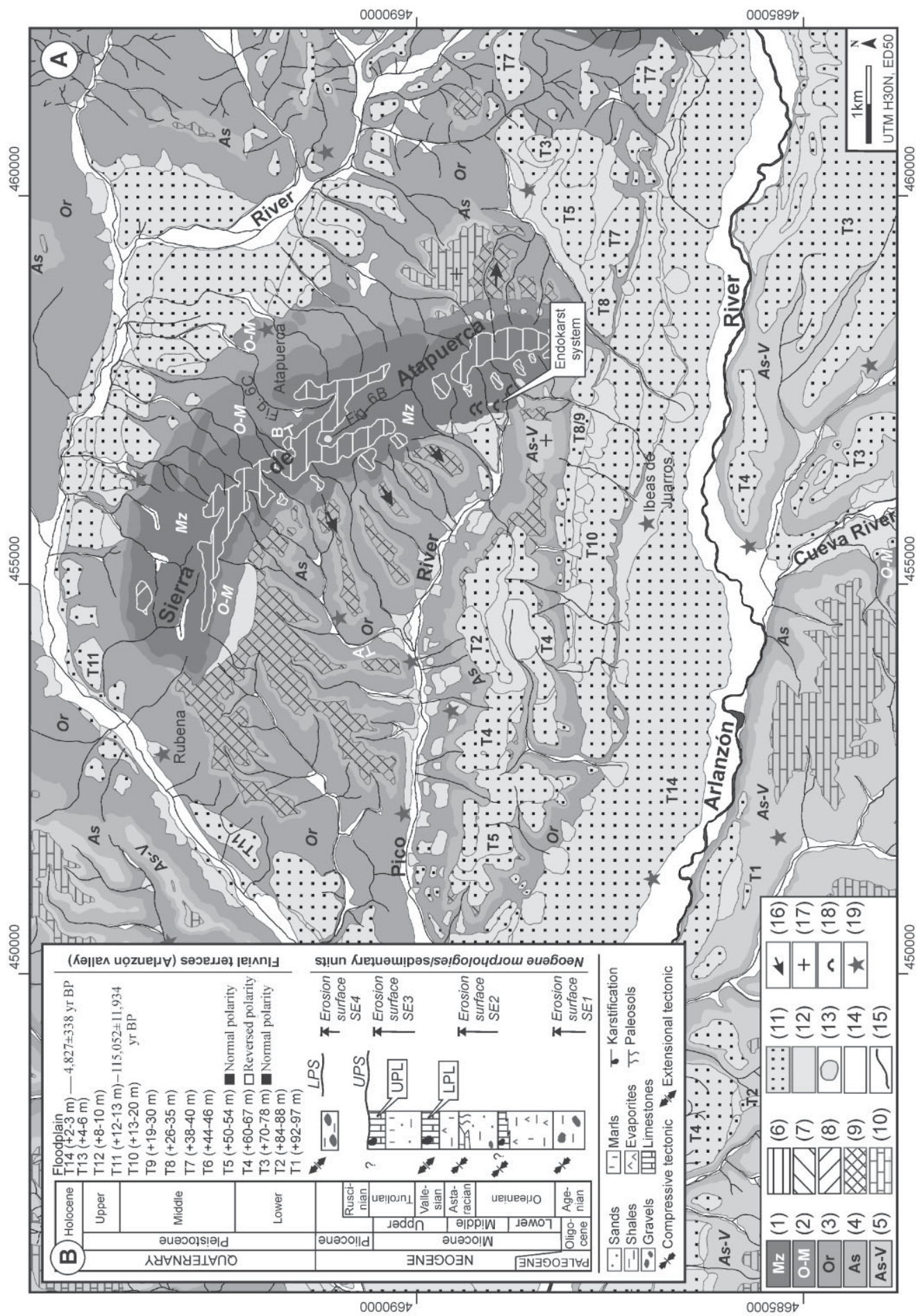

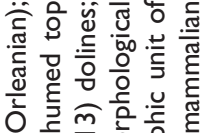

잉 $\stackrel{\frac{m}{2}}{\circ}$

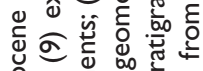
을

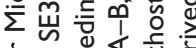
过

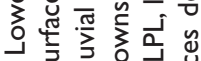

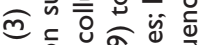

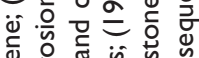
递高

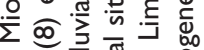
ळ

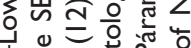

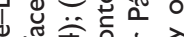

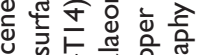

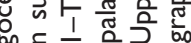

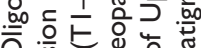

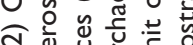

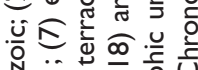
㟧

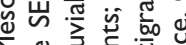
$\Sigma$ \& 气舟 㐫的芒出至

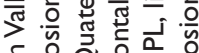

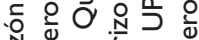

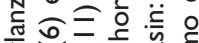

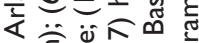

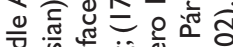

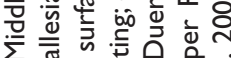

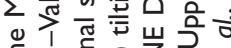

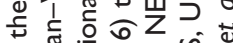

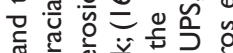
ฮั

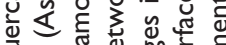

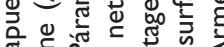
प्र

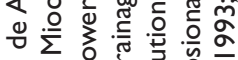

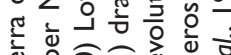

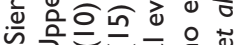

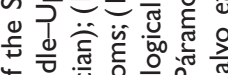

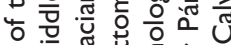

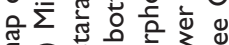

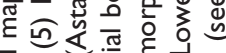

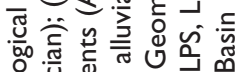

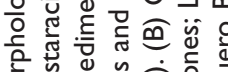

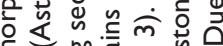

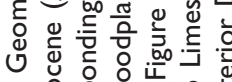

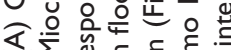
$\leqslant \sum \sum_{0}^{0} \frac{5}{0}$ 은

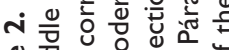

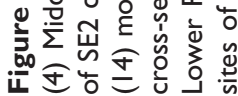




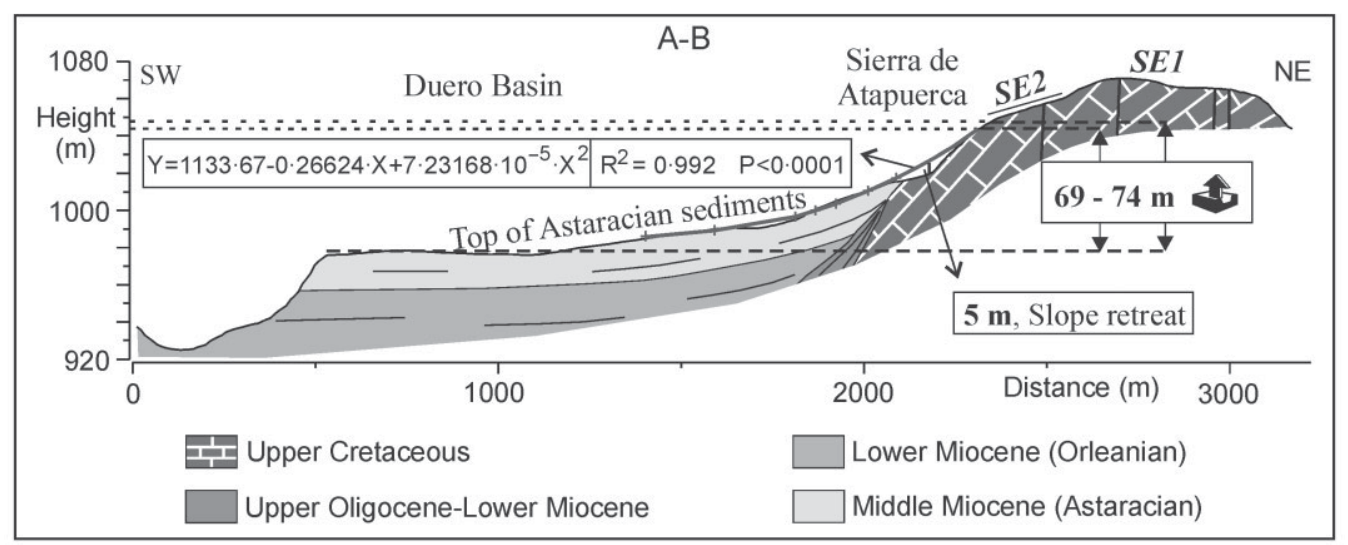

Figure 3. Geological cross-sections of the Sierra de Atapuerca. Quantifying the tectonic uplift of the Astaracian (Middle Miocene) and the slope retreat on the basis of the correlation between erosion surface SE2 with the top of its corresponding sediments. See the explanation in the text.

(Figure 2(A) and (B)). This sequence has also been identified in another of the region's main valleys, the Arlanza Valley, with two older levels $(+107-114 \mathrm{~m},+121-130 \mathrm{~m})$. Dating by thermoluminescence (Laboratorio de Datación y Radioquímica, Universidad Autónoma de Madrid, Spain) conducted on the terraces associated T14 (+2-3 m) to the Holocene $(4827 \pm 338 \mathrm{yr} \mathrm{BP})$ and T11 $(+12-13 \mathrm{~m})$ close to the Middle-Upper Pleistocene transition period (Figure 2(B)), whose equivalent at the River Arlanza indicates an age of $115052 \pm 11934 \mathrm{yr}$ BP. Magnetostratigraphic data (Laboratory of the Department of Geological Sciences, University of Michigan, USA) could suggest an age of Middle Pleistocene for terrace T5 $(+50-54 \mathrm{~m})$, whose polarity is normal, and situate level T4 $(+60-67 \mathrm{~m})$, of reversed polarity, in the Lower Pleistocene (Matuyama Chron). Based on these data, the terrace at $+70-78 \mathrm{~m}$ (normal polarity in Arlanza Valley) would also belong to the Lower Pleistocene (Jaramillo Subchron).

The base levels imposed during the Neogene and Pleistocene have controlled the onset and development of a phreatic endokarst in the Sierra de Atapuerca, which was open during the Lower Pleistocene (Parés and PérezGonzález, 1995; Pérez-González et al., 2001; Parés et al., 2006). The latter caused the entry of allochthonous infills where the archaeopalaeontological remains are located.

\section{Reconstruction Methodology}

Two methodologies have been utilized in the palaeorelief reconstruction, based first on the modelling of geomorphic processes and second on the modelling of palaeosurfaces. Several methods have been combined for the modelling of processes, such as fluvial and karstic process simulations or nonlinear diffusion models of hillslopes (Howard et al., 1994; Kooi and Beaumont, 1994; Howard, 1995; Kaufmann and Braun, 2001; García-Castellanos et al., 2003). However, the application of these methods to the evolution of actual reliefs is limited by lack of knowledge regarding the input parameters (precipitation, temperature, $\mathrm{CO}_{2}$ pressure etc) throughout the Quaternary and Neogene.

For this reason, the reconstruction of palaeoreliefs has been based on the geostatistical modelling of palaeosurfaces or preserved morphologies from each of the relief's formation stages (Abbot et al., 1997; Small and Anderson, 1998; Bonnet et al., 2001). Although this method is limited by the degree of palaeosurface preservation, it has provided a useful approach to the palaeorelief modelling. Long-term palaeorelief reconstruction, where spatial and temporal processes generate palaeosurfaces of different genesis and geometry, makes use of a combination of several geological and geostatistical techniques, that allow us to regenerate the palaeosurfaces accurately and to connect morphologies of coeval age. Our initial data for this work included detailed geological and geomorphological maps (1:10 000), and a raster DEM interpolated from 1:10 000 topographic maps (with contour intervals at $5 \mathrm{~m}$, height points and the drainage network). A root mean square (RMS) of $0.79 \mathrm{~m}$ has been calculated for this DEM from the initial data.

Pleistocene and Holocene base levels were determined from an initial interpretation and reconstruction of valley longitudinal profiles (Benito and Pérez-González, 2005b). Analysis of longitudinal profiles has been carried out in small valleys of the Sierra de Atapuerca and the Neogene Basin, where several slope breaks associated with base level evolution have been detected, and in the main valleys, represented by the Arlanzón River and its greater tributaries (Vena River, Pico River and Cueva River, Figure 2(A)). Fluvial terraces are preserved in the main valleys, terrace edge 


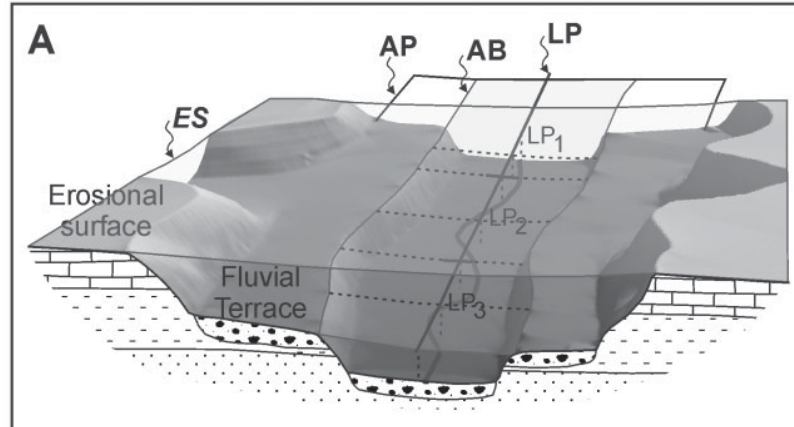

+ LP (Longitudinal profile): $\mathrm{LP}_{1} \cup \mathrm{LP}_{2} \cup \mathrm{LP}_{3}$

$L P_{1-3}: z=z_{0}+a d+b d^{2} \quad z$, height; $d$, distance

$+A B$ (Alluvial bottom): Local trend surface, Quadratic polynomial equations $\left(Z=b 0+b 1 X+b 2 y+b 3 x^{2}+b 4 x y+b 5 y^{2}\right)$ overlapping.

+ AP (Alluvial plain): Ordinary Kriging

Nugget $=\frac{\text { RMS }_{D E M}}{N_{D E M}}+\frac{R M S_{P L}}{N_{P L}}+\frac{R_{A M S}}{N_{A B}}$

RMS, Root mean

$+E S$ (Erosional surface): Ordinary Kriging Nugget $=$ RMS $_{\text {DEM }}$
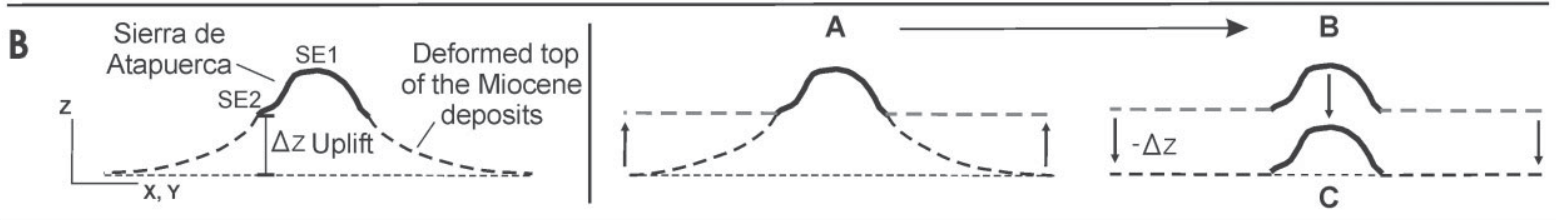

Figure 4. (A) Methodological procedure (polynomial regressions, trend surfaces and ordinary kriging) used for reconstructing Quaternary alluvial levels and erosional surfaces. (B) Geometric method used to model the relief during the final elaboration of erosion surface SE2, from the estimate of Sierra de Atapuerca tectonic uplift and the original horizontal geometry of SE2 corresponding sediments.

heights being used to reconstruct the Quaternary valley longitudinal profiles. Height data have been extracted from the DEM and through total station surveying in the terraces situated next to the Sierra de Atapuerca archaeopalaeontological sites. Reconstructions of longitudinal profiles were performed by applying second-degree polynomial regressions by reaches showing similar trends (Figure 4(A)). The aim was to show the variations characterizing the longitudinal profile of each period. Then, these longitudinal data were used to reconstruct the alluvial bottoms applying local trend surfaces, which fit overlapping polynomial functions following the model pattern defined by the longitudinal profile (Figure 4(A)). The connection between alluvial bottoms was assessed using the ordinary kriging procedure, in which the RMS error accumulated in the interpolations (of DEM, polynomial regressions and local trend surfaces) was weighted according to the contribution of each type of data in the final interpolation, considered as a nugget effect (Figure 4(A)). This method provided an estimate of the spatial variation in the statistical errors in the final alluvial plain models (Johnston et al., 2001).

Several methods were tested for computing the erosional surfaces on Miocene limestones (Upper and Lower Páramo surfaces), including radial functions and spline interpolators (Abbot et al., 1997; Small and Anderson, 1998), although we finally opted for ordinary kriging since this procedure provides an estimate of the model's goodness of fit (Figure 4(A)). As a special case, relief modelling in the Middle Miocene was performed by means of a procedure based on the reconstruction of the geometry between the erosion surface SE2 and its corresponding sediments (Figure 4(B)). The top of SE2 corresponding sediments consists of a layer of lacustrine limestones, currently deformed. This deformation has been removed, restoring the layer to a horizontal position (Figure 4(B)), and then the increment of height estimated for the Middle Miocene uplift has been subtracted from the whole relief. In this way, the final result simulates the relief before the tectonic uplift occurred in the Sierra de Atapuerca (Figure 4(B)).

The reconstruction of Late Cenozoic morphologies was complemented by a necessary approximation of the retreat of slopes, based on relationships between morphologies and materials. The reconstructed palaeosurfaces together with the analysis of slope retreat generated the final palaeo-DEMs.

\section{Palaeosurface Modelling}

Reconstruction of palaeosurface trends has made it possible to model the evolution of the Late Cenozoic base levels. From the Miocene until the Pliocene-Pleistocene boundary, these base levels are products of the balance between uplift stages and erosion-sedimentation processes, and the denudation dynamics of the fluvial drainage network during the Quaternary. 


\section{Neogene palaeosurfaces}

Neogene morphologies which were modelled correspond to erosion surfaces and the top of their corresponding sediments. The oldest morphology considered in the modelling is the erosion surface SE2 (Middle Miocene), since the top of SE1 corresponding sediments is not preserved in the terrain surface.

In the geomorphological analysis carried out between alpine mountains (the Cantabrian and Iberian Ranges) and the NE of the Duero Neogene Basin, erosion surface SE2 has been related to alluvial sediments of Middle Miocene age (Benito-Calvo and Pérez-González, 2007). Around the Sierra de Atapuerca (Figure 3), these sediments are tilted by 2$7^{\circ}$ in contact with the Mesozoic materials and buried by horizontal Middle-Upper Miocene deposits (Figure 2(A) and (B)). The geostatistical reconstruction of the deformed top of Astaracian sediments has facilitated its correlation with the erosion surface SE2, preserved on the Upper Cretaceous carbonates (Figure 3). This has allowed us to estimate the tectonic uplift of the Sierra de Atapuerca during the Astaracian (Middle Miocene), before the sedimentation of the Middle-Upper Miocene unit, at 69-74 m. The maximum inferred for this uplift (74 m) and the original horizontal geometry of the corresponding sedimentary surface (the layer of lacustrine limestones) have been used to reconstruct the relief of the Sierra de Atapuerca before this uplift. This correlation also provides an interesting relationship in estimating slope retreat ( $5 \mathrm{~m}$, Figure 3).

During the Upper Miocene-Pliocene the basin is characterized by the formation of the Páramo erosional surfaces (Upper and Lower Páramo surfaces), which are closely linked to the formation of erosion surfaces SE3 and SE4 respectively (see Figure 2(B)). The Páramo surfaces, apart from defining accurately the Neogene landscape, also provide a good indication of the Upper Miocene limestone surface at which they developed. Consequently, these surfaces identify the position of Miocene sedimentary systems, whose phreatic levels could have initiated the endokarst system of the Sierra de Atapuerca (Zazo et al., 1983).

The Upper Páramo erosional surface (Upper Miocene-Pliocene) is preserved outside the study area, in sites located to the south of Arlanzón Valley, in the Bureba Corridor and in the centre of the Neogene Basin (Benito and PérezGonzález, 2005a). These Upper Páramo remnants have been used to reconstruct the regional trends of this surface. Given the scarce presence of the Upper Páramo surface, the prediction model presents higher RMS values (see Figure 5), showing a topography inclined to the north and west, with a mean elevation of $1027 \mathrm{~m}$ and a mean slope of $0 \cdot 26^{\circ}$. The predicted surface (Figure 5) allows us to estimate the top of the Miocene endorrheic infill, which onlaps the Sierra de Atapuerca at 1031-1040 m a.s.l., occupying a similar level to erosion surface SE3.

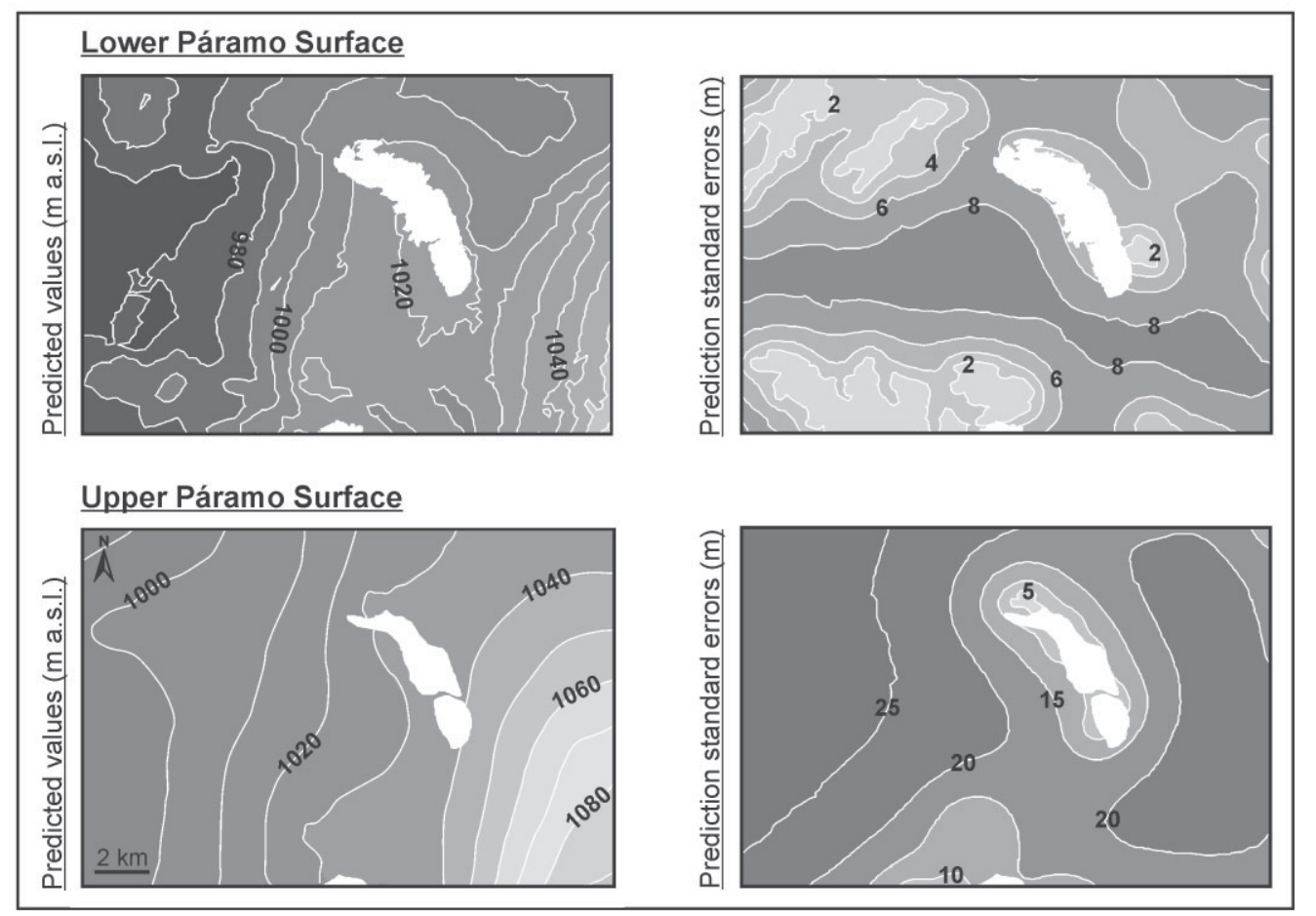

Figure 5. Estimates of Páramo erosional surfaces using geostatistical interpolation (ordinary kriging) from preserved topography of these Neogene morphologies. On the right the standard error maps of the kriging predictions are shown. 
In the study area, the Lower Páramo erosional surface extends over $17.7 \mathrm{~km}^{2}$ and forms the outer part of the main valleys (Figure 2(A)). The model constructed for the Lower Páramo erosional surface from its preserved topography, for which the predicted surface and standard error maps are shown in Figure 5, presents an irregular surface developed between $1072 \mathrm{~m}$ to the south-east and $962 \mathrm{~m}$ to the west, with a mean elevation of $1001 \mathrm{~m}$. Slope is characterized by a mean value of $0.49^{\circ}$ and a maximum value of $7 \cdot 2^{\circ}$. Although the regional trend of this plane shows an inclination towards the Neogene Basin, several depressions and flat areas can also be observed. The larger depressions have an orientation similar to the current drainage network, constituting the palaeoforms of Quaternary valleys. To the west of Sierra de Atapuerca, a palaeovalley having a depth of 14-20 m can be distinguished, from which the Vena and Arlanzón Valleys have developed (Figure 5). Around the southern tip of the Sierra de Atapuerca, the predicted Lower Páramo surface is situated at 1020-1024 m a.s.l. (Figure 5), coinciding with the position where upper level galleries of the Sierra de Atapuerca endokarst system have developed (1015-1020 m a.s.l., Ortega et al., 2005). This correlation would imply that the endokarst started to form in response to phreatic levels imposed by the Upper AstaracianVallesian lakes, where the Lower Páramo Limestones were deposited.

\section{Quaternary fluvial morphologies}

By reconstructing fluvial plains, we were able to establish the evolution of base levels during the Pleistocene and the Holocene (Figure 6). The reconstruction is based on the data obtained from an initial analysis of valley longitudinal profiles (Benito and Pérez-González, 2005). This analysis included the restitution of Quaternary longitudinal profiles in the valleys which preserve fluvial terraces, and the interpretation of current longitudinal profiles in minor valleys. The latter has allowed us to correlate the evolution of minor valleys with the base levels imposed by the main drainage network and older morphologies.

The restitution of Quaternary longitudinal profiles has been carried out in the Arlanzón Valley, and its main tributaries (Vena, Cueva and Pico Valleys). The reconstruction of Arlanzón longitudinal profiles from polynomial regressions applied by reaches $\left(R^{2}>0.967\right)$ defines trends for the alluvial plains and has allowed detection of several breaks of slope. Some of these breaks can be recognized in the current longitudinal profile too (Figure 6(A)), and may be explained by inferring the presence of substrate fractures. The latter explain the E-W rectilinear direction of the Arlanzón Valley in this area, and the difference in the position and thickness of the Neogene facies on the two sides of the valley (Figure 2(A)). In the longitudinal profiles T4-T7 other breaks related to lithological factors can be observed (Figure 6(A)), due to the presence of resistant subhorizontal limestones of Miocene age.

In the longitudinal profiles of the minor valleys situated in the Sierra de Atapuerca and the Neogene Basin, slope breaks have been recognized too, although these cannot be explained by lithological or structural factors (Figure 6(B) and $(\mathrm{C})$ ). However, these breaks can be correlated with the base levels marked by regional morphologies, suggesting that each is a complex longitudinal profile (Selby, 1985), consisting of reaches generated during the Pleistocene, Pliocene and Miocene base levels. The latter are still preserved because of the slow response of the secondary network to successive declines in the base level.

These data from the longitudinal profiles and the topography of preserved terraces have been used to model the alluvial plains using a local polynomial interpolator and then ordinary kriging. These interpolation techniques have allowed us to reflect in three dimensions the Quaternary valley evolution observed in the longitudinal profile analysis (Figure 7(C) and (D)). The prediction errors of alluvial plains related to the interpolation procedure were estimated as between RMSs of 0.94 and $2.03 \mathrm{~m}$. These errors were calculated applying the cross-validation method in the kriging interpolation (Johnston et al., 2001). The alluvial plain extension shows a reduction from the Lower Pleistocene (T2, $87.4 \%$ of the terrain), when alluvial deposits reached the Mesozoic carbonates of the Sierra de Atapuerca, to the present, when they only represent $8.4 \%$ of the landscape, filling incised valleys in the Neogene deposits.

\section{Slope Retreat}

Slope retreat in the western half of the Duero Basin is closely related to the thickness of Miocene limestones beneath which the valley slopes or cuestas developed. In the zones of low thickness (5-8 m, in the Almazán Subbasin) talus flatirons are associated with the limestone scarp retreat during the Pleistocene and Holocene (Gutiérrez Elorza and Sesé Martínez, 1999). However, in the central basin or in the Burgos area, where the limestone thickness is up to 17$25 \mathrm{~m}$, the slopes show a slow retreat.

In the study area, several geomorphological observations support this limited slope retreat. Such observations include the restricted vertical evolution of the longitudinal profiles in the smaller valleys of the Sierra de Atapuerca and the Neogene Basin, which still show reaches developed in relation to Pleistocene and Neogene basal levels 


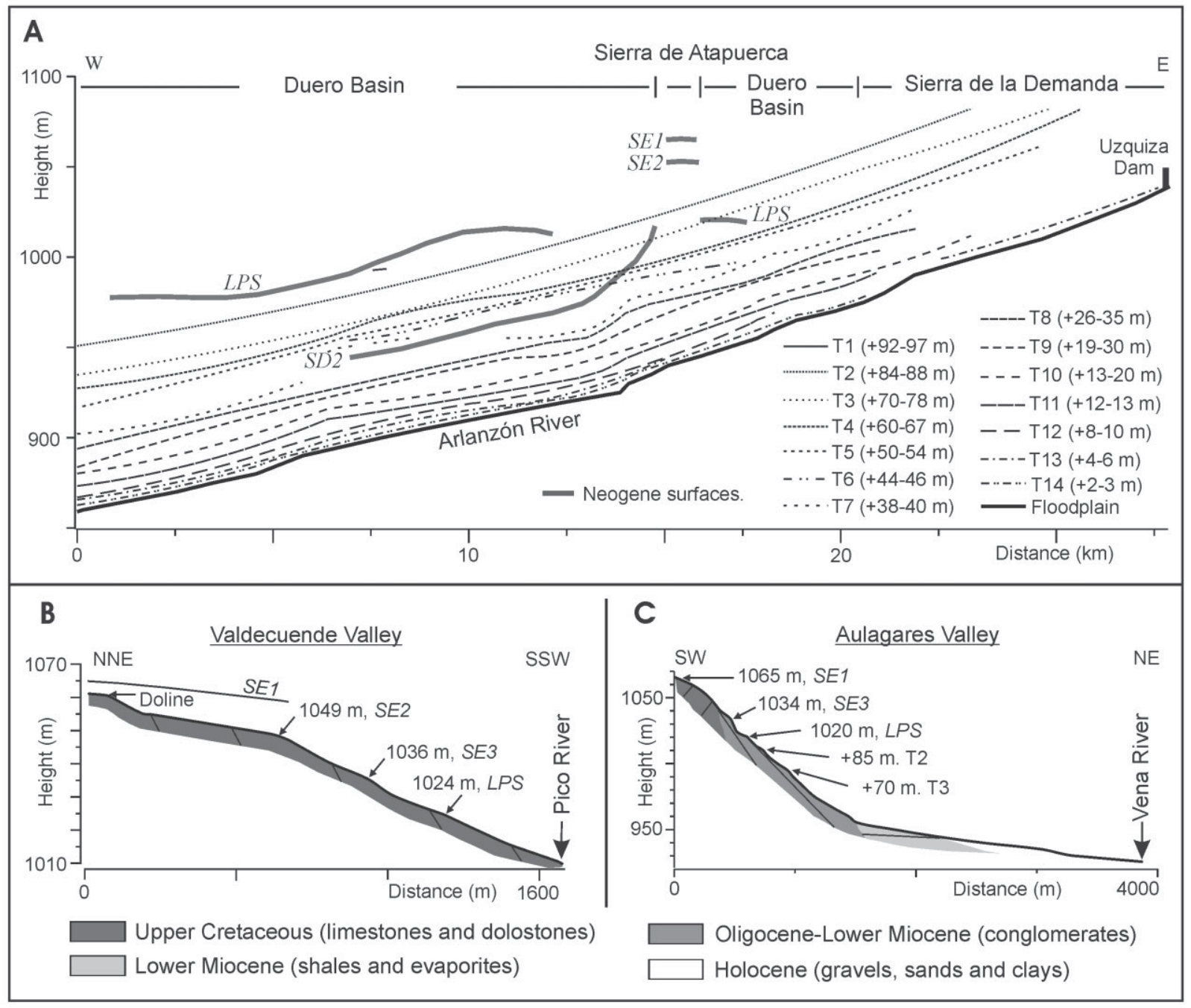

Figure 6. Analysis and reconstruction of valley longitudinal profiles. (A) Pleistocene and Holocene longitudinal profiles reconstructed in the Arlanzón Valley applying polynomial regressions by reaches, and its location with respect to the Neogene surfaces. (B), (C) Correlation of longitudinal profile breaks of Sierra de Atapuerca valleys with Neogene and Pleistocene base levels (see valley locations in Figure 2(A)). LPS, Lower Páramo erosional surface; SEI, erosion surface SEI; SE2, erosion surface SE2; SD2, top of SE2 corresponding sediments; TI and T2, Lower Pleistocene fluvial terraces.

(Figure 6(B) and (C)), or the stepped downcutting evolution of the main valleys, which are lowered to the Neogene surfaces. The presence of Neogene materials and morphologies, for example the Lower Páramo surface in contact with the Sierra de Atapuerca, indicates a slow evolution of these slopes too. A more precise relationship has been established regarding the correlation between erosion surface SE2 and the surface of the Astaracian deposits (Figure 3), which is located close to the present-day topography of the slopes (maximum difference $5 \mathrm{~m}$ ). Retreat rates have been determined at $0.0384 \mathrm{~cm} / \mathrm{ky}$ if we consider the SE2 surface age to be about $13 \mathrm{Ma}$ (Astaracian), or rates of $0.27 \mathrm{~cm} / \mathrm{ky}$ taking into account the exhumation age of the area below 1032-1035 m a.s.l., a value obtained from the Upper Páramo surface reconstruction, which was preserved by Upper Miocene sediments until the Plio-Pleistocene.

\section{Final Paleorelief Models}

Once we reconstructed the three-dimensional morphologies, and considered that at the working scale the slopes have played a minor role in the relief evolution, we then used the current slope topography to articulate the relief between 


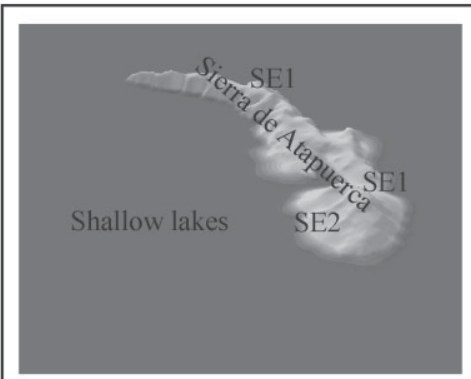

A. Age: Astaracian (Middle Miocene) Coeval morphology: Erosion surface SE2

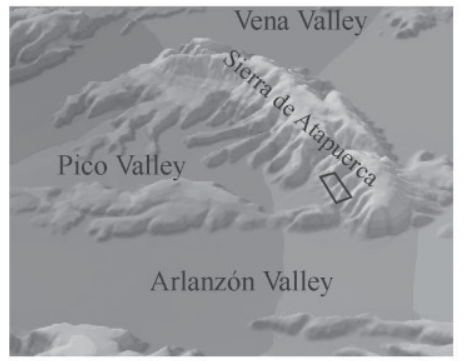

D. Age: Middle Pleistocene Coeval morphology T7 (+38-40 m)

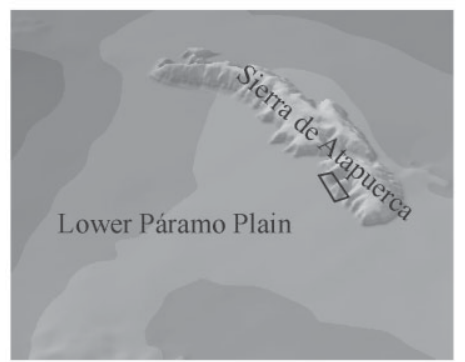

B. Age: Plio-Pleistocene Coeval morphology: Lower Páramo surface

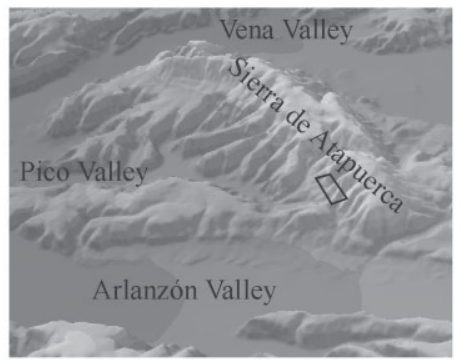

E. Age: Middle-Upper Pleistocene Coeval morphology: T11 (+12-13 m)

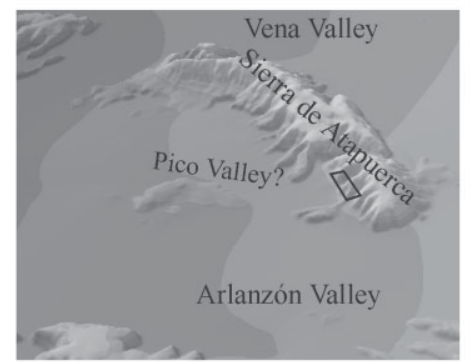

C. Age: Lower Pleistocene Coeval morphology: T4 (+60-67 m)

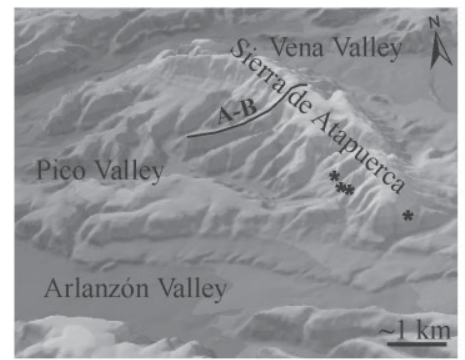

F. Holocene, current situation * Archaeopalaeontological sites $\checkmark$ Endokarst system location

Figure 7. Perspectives of the more representative palaeo-DEMs reconstructed in the Sierra de Atapuerca surrounding area $((A)-(E))$, together with the present-day DEM (F). Line A-B: geomorphological cross-section (Figure 3). These models show the palaeolandscape evolution before the Middle Miocene uplift (A), during overtopping of the Neogene Basin and the first exorrheic processes $(B)$ and in the Quaternary stages of fluvial incision $((C)-(E))$. Note the evolution of the regional base levels with respect to the position of the endokarst system.

the reconstructed morphological levels (Leverington et al., 2002). The results of this combination are shown in Figure 7. They represent five 3D visualizations extracted from the 12 reconstructed palaeorelief models that define the Late Cenozoic landscape evolution of this area.

In the Middle Miocene, the landscape consisted of a shallow lake, developed at the distal front of alluvial fans, in which the Sierra de Atapuerca was uplifted with a piedmont (SE2 surface), beneath the SE1 altiplain (Figure 7(A)). Already in this epoch, the upper watershed of the small valleys, which today cross the Sierra de Atapuerca, could be observed (Figure 7(A)). After the tectonic uplift of the Astaracian, the endorrheic overtopping of the Neogene Basin continued, finishing in the Upper Miocene, while erosion surface SE3 formed in the Sierra de Atapuerca. In the Neogene Basin, a vast plain developed on Upper Miocene limestones, the Upper Páramo erosional surface (Figure 7). With the opening of the Duero Basin into the Atlantic Ocean after endorrheic infill (Pliocene), denudation processes commenced, which gave rise to the incision of the Vallesian limestones and the formation of the Lower Páramo erosional surface (Figures 5 and 7(B)). In this period, the general orientations of Quaternary valleys were established.

The first fluvial stages were characterized by extensive alluvial plains which surrounded the Sierra de Atapuerca, associated with the Vena and Arlanzón Rivers, and developed below the Neogene erosional surfaces (Figure 7(C)). At about the end of the Lower Pleistocene, Pico Valley began to form, probably related to the karstic springs of Sierra de Atapuerca endokarst (Figure 7(C)), piezometric levels of which were controlled by Arlanzón phreatic levels. Successive declines in base level during the Quaternary would have triggered the incision of the Arlanzón River and led to secondary network differentiation (Figure 7(D) and (E)), producing the lowering of the phreatic level that fed the endokarst system. Phreatic levels related to the Arlanzón River were situated under the known endokarstic system from T9 (+19-30 m), at the end of the Middle Pleistocene. 


\section{Conclusions}

Palaeosurface reconstruction using GIS, DEM and geostatistical tools presents a useful approach to landscape modelling, providing quantitative criteria with which to correlate morphologies and geologic events. These techniques have been applied to the modelling of Neogene erosive morphologies, allowing us to estimate the uplift of the Sierra de Atapuerca in the Middle Miocene, and to reconstruct the relief before this tectonic stage (Figure 7(A)) and during the Upper Miocene-Pliocene (Páramo surfaces). Modelling of these surfaces contributes quantitative criteria by which to correlate the origin of the Sierra de Atapuerca endokarst with lacustrine systems of the Upper Miocene (Vallesian). The reconstruction of Quaternary base levels provides valuable information about downcutting and suggests that the endokarst system was fed by phreatic levels of the Arlanzón River until the end of the Middle Pleistocene.

Moreover, these models or palaeo-DEMs provide a valuable database which can facilitate palaeolandscape and palaeoenvironmental studies. An initial statistical analysis may be carried out of the main morphometric variables (Figure 8). The Neogene and Quaternary geomorphological evolution of this area has increased the terrain complexity and process diversity, defined by an increase of slope values and of concave and convex forms (Figure 8(A) and (C)). The slope increase shows thresholds (Figure 8(A)), associated with the valley incision in resistant materials during the later Neogene and Lower Pleistocene (the Mesozoic and horizontal Miocene limestones) and with present anthropogenic activities (mining). This trend has caused a decrease of horizontal-subhorizontal terrains (slopes between 0 and $0.5^{\circ}$ and curvatures close to $0 \mathrm{~m}^{-1}$, Figure $8(\mathrm{~B})$ and (D)), and a significant increase of terrains between 0.5 and $15^{\circ}$, characterized by runoff processes, mass movement and the triggering of landslides. The curvature shows a decrease of

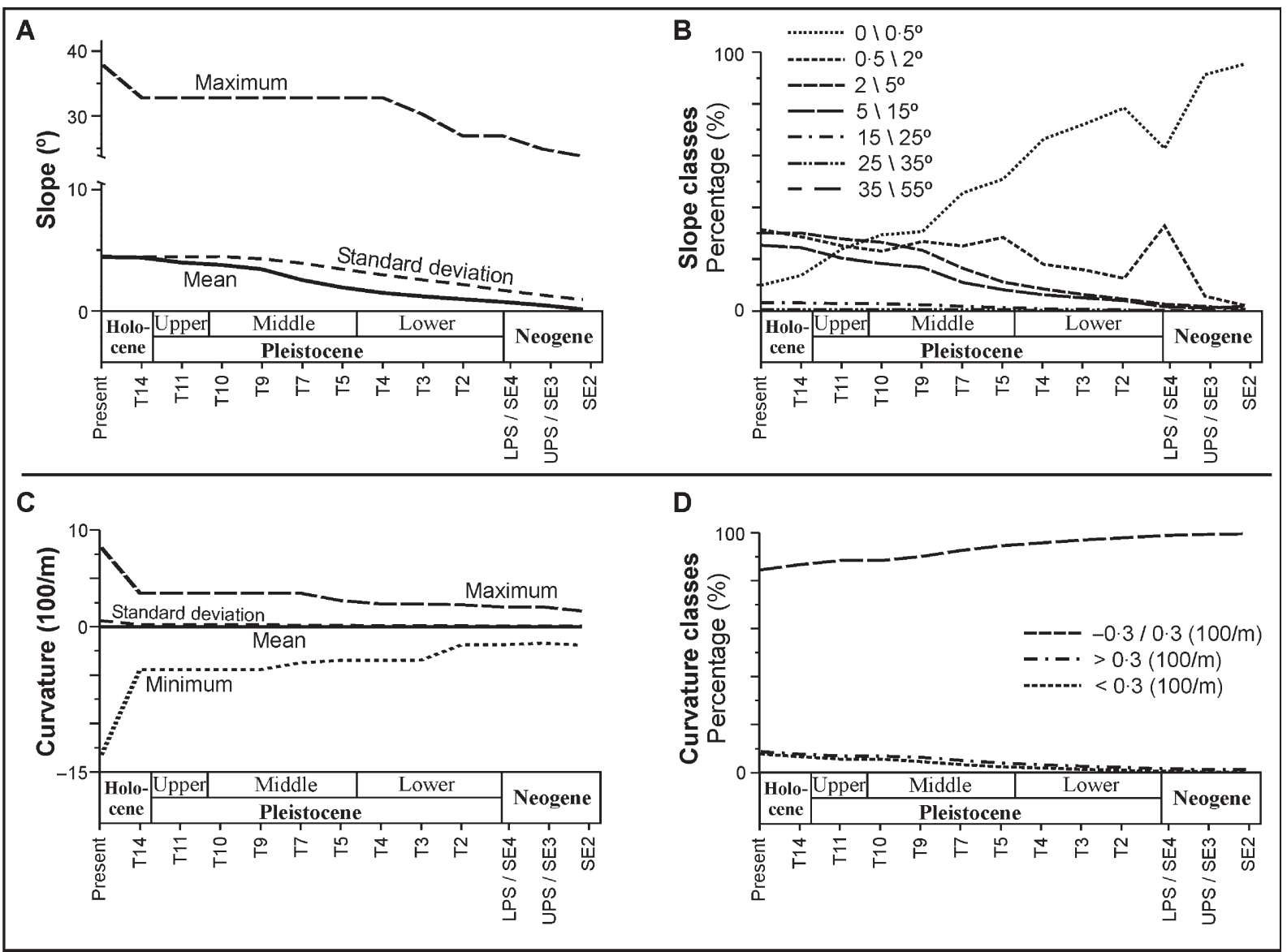

Figure 8. Evolution of slope and tangential curvature variables during the Neogene and Quaternary, using reconstructed palaeoDEMs (see geomorphological stages of $X$-axis in Figure 2(B)). (A) Variation of slope statistics; (B) variation of slope class distribution; $(C)$ variation of tangential curvature statistics; $(D)$ variation of tangential curvature class distribution. 
flat terrains (tangential curvatures close to $0 \mathrm{~m}^{-1}$ ) and an increase of concave and convex forms (Figure 8(C) and (D)), associated with the phase of greater incision in the Sierra de Atapuerca narrow valleys (T3) and the current anthropogenic uses.

\section{Acknowledgements}

This study was supported by research projects BXX2000-1258-03-02, BOS2003-08938-C03-01 and CGL2006-13532C03-02 of the DGICYT, and by the Junta de Castilla y León (Spain). The authors thank the archaeopalaeontological research team of the Sierra de Atapuerca for constant scientific and logistic support. The authors also thank two anonymous reviewers for the careful revision of the manuscript.

\section{References}

Abbot LD, Silver EA, Robert SA, Smith R, Ingle JC, Kling SA, Haig D, Small E, Gaqlewsky J, Sliter W. 1997. Measurement of tectonic surface uplift rate in a young collisional mountain belt. Nature 385: 501-507.

Alonso JL, Pulgar JA, García-Ramos JC, Barba P. 1996. The Duero Basin: a general overview. In Tertiary Basins of Spain: the Stratigraphic Record of Crustal Kinematics, Friend PF, Dabrio CJ (eds). Cambridge University Press: Cambridge; 214-227.

Armenteros I, Corrochano A, Alonso-Gavilán G, Carballeira J, Rodríguez JM. 2002. Duero Basin (northern Spain). In Geology of Spain, Gibbons W, Moreno T (eds). Geological Society: London; 309-315.

Arsuaga JL, Carretero JM, Lorenzo C, Gracia A, Martínez I, Bermúdez de Castro JM, Carbonell E. 1997. Size variation in Middle Pleistocene humans. Science 277: 1086-1088.

Benito A. 2004. Análisis Geomorfológico y Reconstrucción de los Paleopaisajes Neógenos y Cuaternario en la Sierra de Atapuerca y el Valle Medio del Río Arlanzón, PhD Thesis, Universidad Complutense, Madrid.

Benito A, Pérez-González A. 2005a. Las superficies erosivas de los páramos en el sector NE de la Cuenca del Duero y sus implicaciones en el conexión neógena Duero-Bureba. Boletín Geológico y Minero 116: 351-360.

Benito A, Pérez-González A. 2005b. Restitución estadística de los perfiles longitudinales fluviales en el valle medio del río Arlanzón: primeros resultados de la reconstrucción de paleo-relieves cuaternarios en la Sierra de Atapuerca. In Geoarqueología y Patrimonio en la Península Ibérica y el Entorno Mediterráneo, Santonja M, Pérez-González A, Machado M (eds). ADEMA: Almazán; 449-459.

Benito-Calvo A, Pérez-González A. 2007. Erosion surfaces and Neogene landscape evolution in the NE Duero Basin (north-central Spain). Geomorphology 88: 226-241.

Bermúdez de Castro JM, Arsuaga JL, Carbonell E, Rosas A, Martínez I, Mosquera M. 1997. A hominid from the lower Pleistocene of Atapuerca, Spain: possible ancestor to Neandertals and modern humans. Science 276: 1392-1395.

Bonnet S, Bernard M, Driessche JV. 2001. Drainage network expansion of the Salagou drainage basin (S. France): an example of relief response to recent climate change? Terra Nova 13: 214-219.

Calvo JP, Daams R, Morales N, López-Martínez N, Agustí J, Anadón P, Armenteros I, Cabrera L, Civis J, Corrochano A, Díaz-Molina M, Elizaga E, Hoyos M, Martín-Suárez E, Martínez J, Moissenet E, Munóz A, Pérez-García A, Pérez-González A, Portero JM, Robles F, Santisteban C, Torres T, Van der Meulen AJ, Vera JA, Mein P. 1993. Up-to-date Spanish continental Neogene synthesis and paleoclimatic interpretation. Revista de la Sociedad Geológica de España 6: 29-40.

Carbonell E, Bermúdez de Castro JM, Arsuaga JL, Allue E, Bastir M, Benito A, Cáceres I, Canals T, Díez JC, van der Made J, Mosquera M, Ollé A, Pérez-González A, Rodríguez J, Rodríguez XP, Rosas A, Rosell J, Sala R, Vallverdú J, Vergés JM. 2005. An Early Pleistocene hominin mandible from Atapuerca-TD6, Spain. PNAS 102: 5674-5678.

García-Castellanos D, Vergés J, Gaspar-Escribano J, Cloething S. 2003. Interplay between tectonics, climate, and fluvial transport during the Cenozoic evolution of the Ebro Basin (NE Iberia). Journal of Geophysical Research 108(B7): 2347. DOI: 10.1029/2002JB002073

Gutiérrez-Elorza M, Gracia FJ. 1997. Environmental interpretation and evolution of the Tertiary erosion surfaces in the Iberian Range (Spain). In Palaeosurfaces: Recognition, Reconstruction and Palaeoenvironmental Interpretation, Geological Society Publication 120, Widdowson M (ed.); 147-158.

Gutiérrez Elorza M, Sesé Martínez VH. 1999. Cálculo de retrocesos de escarpes de la Cuenca de Almazán y significación climática de la evolución de laderas (Depresión oriental del Duero). Boletín Geológico y Minero 110: 581-590.

Hernaiz PP, Serrano A, Malagón J, Rodríguez Cañas C. 1994. Evolución estructural del margen SO de la cuenca Vasco-Cantábrica. Geogaceta 15: 143-146.

Howard AD. 1995. Simulation modeling and statistical classification of escarpment platforms. Geomorphology 12: 187-214.

Howard AD, Dietric WE, Seild A. 1994. Modeling fluvial erosion on regional to continental scales. Journal of Geophysical Research 99: 13971-13986.

Johnston K, Ver Hoef JM, Krivoruchko K, Lucas N. 2001. Using ArcGIS Geostatistical Analyst. ESRI.

Kaufmann G, Braun J. 2001. Modelling karst denudation on a synthetic landscape. Terra Nova 13: 313-320.

Kooi H, Beaumont C. 1994. Escarpment evolution on high-elevation rifted margins: insights derived from a surface processes model that combines diffusion, advection, and reaction. Journal of Geophysical Research 99: 12191-12209.

Leverington DW, Teller JT, Mann JD. 2002. A GIS method for the reconstruction of late Quaternary landscapes from isobase data and modern topography. Computers and Geosciences 28: 631-639. 
Mikes D, Vergés J, Fernàndez M, García-Castellanos D, Pineda-Velasco A, Peña-Monné J-L, Plaza J. 2004. La evolución de los sistemas fluviales del Ebro y el Duero durante el Cenozoico superior. Geotemas 6(2): 187-189.

Ortega AI, Pérez-González A, Martín M, Carretero JM, Arsuaga JL. 2005. El Sistema Cueva Mayor-Cueva del Silo: un estudio morfogenético del endokarst de la Sierra de Atapuerca (Burgos, España). In Geoarqueología y Patrimonio en la Península Ibérica y el Entorno Mediterráneo, Santonja M, Pérez-González A, Machado M (eds). ADEMA: Almazán; 163-182.

Parés JM, Pérez-González A. 1995. Paleomagnetic age for hominid fossils at Atapuerca archaeological site, Spain. Science 269: 830-832.

Parés JM, Pérez-González A, Rosas A, Benito A, Bermúdez de Castro JM, Carbonell E, Huguet R. 2006. Matuyama-age lithic tools from the Sima del Elefante site, Atapuerca (northern Spain). Journal of Human Evolution 50: 163-169.

Pérez-González A, Parés JM, Cardonell E, Aleixandre T, Ortega AI, Benito A, Martín MA. 2001. Géologie de la Sierra de Atapuerca et stratigraphie des remplissages karstiques de Galería et Dolina (Burgos, Espagne). L'Anthropologie 105: $27-43$.

Pineda A. 1996. El enlace y la paleogeografía neógena entre las cuencas del Duero y del Ebro en la Bureba (Burgos). Boletín Geológico y Minero 107: 14-28.

Santisteban JI, Mediavilla R, Martín-Serrano A, Dabrio CJ. 1996. The Duero Basin: a general overview. In Tertiary Basins of Spain: the Stratigraphic Record of Crustal Kinematics, Friend PF, Dabrio CJ (eds). Cambridge University Press: Cambridge; $183-187$.

Selby MJ. 1985. Earth's Changing Surface. An Introduction to Geomorphology. Clarendon: Oxford.

Simón JL. 2004. La tectónica extensional neógena-cuaternaria en la Cordillera Ibérica. In Geología de España, Vera JA (ed.). SGE, IGME: Madrid; 615-617.

Simón JL, Liesa CL, Arlegui LE. 2002. The Iberian Ranges. In Geology of Spain, Gibbons W, Moreno T (eds). Geological Society: London; $385-400$.

Small EE, Anderson RS. 1998. Pleistocene relief production in Laramide mountain ranges, western United States. Geology 26: $123-126$.

Vergés J, Fernàndez M, Martínez A. 2002. The Pyrenean orogen: pre-, syn-, and post-collisional evolution. Journal of the Virtual Explorer 8: $55-74$.

Zazo C, Goy JL, Hoyos M. 1983. Estudio geomorfológico de los alrededores de la Sierra de Atapuerca (Burgos). Estudios Geológicos 39: $179-185$. 